\title{
Effect of sperm number and site/technique of insemination on pregnancy in mares
}

\author{
Harald Sieme ${ }^{1,3}$ Anna Bonk2, Jochen Ratjen², Erich Klug and Detlef Rath ${ }^{4}$ \\ National Stud of Lower Saxony, Celle1, Clinic for Horses², Institute for Reproductive Medicine ${ }^{3}$, Veterinary School Hanover and Institute of Animal Science, \\ Mariensee $(\mathrm{FAL})^{4}$
}

\begin{abstract}
Summary
This survey reviews data currently published in literature with respect to the effects of sperm number and different artificial insemination (Al) techniques (e.g.: routine insemination into the uterine body, rectally or ultrasonographically guided deep intracornual insemination ipsilateral to the preovulatory follicle, hysteroscopic insemination onto the uterotubal junction ipsilateral to the preovulatory follicle) on the pregnancy rate in mares. It is concluded that a single insemination close to ovulation with reduced numbers of cooled [ $\sim 25-100 \times 10^{6}$ progressive motile spermatozoa (pms) instead of $\left.\sim 300-1.000 \times 10^{6} \mathrm{pms}\right]$ or frozen/thawed $\left[\sim 25-100 \times 10^{6}\right.$ pms postthaw instead of either a total of $800 \times 10^{6}$ frozen spermatozoa with a post thaw motility of $\Delta 35 \%$ or $300 \times 10^{6} \mathrm{pms}$ ] semen from fertile stallions may achieve pregnancy rates similar to commercial doses (Minimum Standard requirements of WBFSH) under optimum conditions. However it remains questionable, whether or not this similarity can be attributed to the use of low dose insemination techniques. Sperm doses $\Delta 25 \times 10^{6}$ pms post-thaw, when inseminated deep intrauterinely with the help of a videoendoscope hold no advantage over conventional uterine body Al. When inseminating with $<10 \times 10^{6}$ pms post-thaw the mares should be inseminated hysteroscopically. This amount of spermatozoa is therefore considered to be close to the critical sperm number. When only very low numbers of spermatozoa (e.g. sex-sorted spermatozoa) are available the critical sperm dose seems to be close to $5 \times 10^{6}$ spermatozoa and should be transfered hysteroscopically rather than by rectally or ultrasonographically controlled deep intrauterine insemination to give the best results. Washing of spermatozoa preceeding insemination to remove damaged spermatozoa and debris seems to have no beneficial effect on pregnancy rates when low doses of spermatozoa are transferred hysteroscopically. Neither does preinsemination intrauterine treatment with prostaglandin E2. This hormone influences oviductal smooth muscle function and subsequent oviductal sperm colonization. Giving prostaglandin E2 prior to low dose transrectallyguided or hysteroscopic-guided deep intrauterine insemination was not seen to increase pregnancy rates in mares. Twin pregnancy rates may be lower after contralateral double ovulations when mares are inseminated deep into the uterine horn on the side of the major preovulatory follicle. Rectally guided deep intrauterine insemination technique may be more feasible for practitioners in the field when inseminating low doses of spermatozoa, but there may be a higher risk of uterine trauma compared to hysteroscopic Al. On the other hand, hysteroscopic $\mathrm{Al}$ is an expensive technique and requires skilled operators. In mares with an overlarge uterus or cases of excessive endometrial edema (foal heat) it could become impossible to locate the uterotubal junction (UTJ). Nevertheless, health risks associated with deep intracornual insemination warrant its further research before extensive use. Application of low dose insemination techniques for less fertile stallions is highlighted in the literature but its usefulness is debatable and further research is required into stallion sperm parameters that may or may not be compensable by the insemination technique.
\end{abstract}

Keywords: low dose insemination; stallion semen, hysteroscopic insemination, sperm number, fertility

Einfluss der Spermiendosis und der Lokalisation der Spermadeponierung bzw. Technik der Samenübertragung auf das Trächtigkeitsergebnis bei Stuten

Dieser Übersichtsartikel fasst die bislang veröffentlichten Daten zusammen, soweit sie sich auf Effekte der Spermiendosis und der Besamungstechnik (konventionelle Samenübertragung in den Gebärmutterkörper, rektal oder sonographisch geleitete tief intracornuale Besamung ipsilateral zum präovulatorischen Follikel, hysteroskopisch geleitete Samenübertragung auf die uterotubale Verbindung ipsilateral zum präovulatorischen Follikel) auf das Trächtigkeitsergebnis bei der Stute beziehen. Zusammenfassend lässt sich feststellen, dass Einzelbesamungen in zeitlicher Nähe zur Ovulation mit reduzierten Spermienzahlen flüssigkonserviertem $\left[\sim 25-100 \times 10^{6}\right.$ progressiv motile Spermien (pms) im Vergleich zu kommerziell empfohlenen Spermiendosen $\sim 300-1000 \times 10^{6}$ pms] oder tiefgefrorenem [ $\sim 25-100 \times 10^{6}$ pms im Vergleich zu kommerziellen Richtwerten: $800 \times 10^{6}$ mit einer Auftaurate von $\Delta 35 \%$ pms oder $300 \times 10^{6}$ pms] Hengstsperma von fertilen Hengsten unter optimierten Besamungskonditionen Fruchtbarkeitsresultate erzielbar sind, welche sich von den Ergebnissen nach Besamung mit ausreichend dosiertem kommerziellem Sperma (Richtwerte WBFSH) nicht deutlich unterscheiden. Ob diese Ergebnisse auf Effekte der Besamungstechnik zurückzuführen sind ist nicht ausreichend geklärt. Wird eine Tiefgefrierspermadosis von $\Delta 25 \times 10^{6}$ pms eingehalten scheinen keine Vorteile der hysteroskopischen im Vergleich zur konventionellen Samenübertragung zu bestehen. Wird Tiefgefriersperma mit $<10 \times 10^{6}$ pms versamt sollte ausschließlich die hysteroskopische Methode eingesetzt werden; so dass diese Dosis als kritische Spermiendosis angesehen werden könnte. Sind nur sehr geringe Spermienzahlen verfügbar (z.B. gesextes Sperma) so scheint die kritische Spermiendosis bei $5 \times 10^{6}$ pms zu liegen, wobei tiefintracornual und bevorzugt hysteroskopisch besamt werden sollte. Das Waschen von Spermien mit speziellen Separationstechniken zur Entfernung von Zelldetritus und geschädigter Spermien präinseminationem hat keinen positiven Effekt auf das Trächtigkeitsergebnis bei hysteroskopischer Samenübertragung. Ebensowenig ließ sich präinseminationem durch prätubale Applikation von Prostaglandin E2 - zum Zwecke der Beeinflussung der glatten Muskulatur des Eileiters - das Trächtigkeitsergebnis nach rektal geleiteter tiefintracornualer oder hysteroskopischer Besamung verbessern. Zwillingsträchtigkeitsraten bei contralateraler Doppelovulation erschienen reduziert nach tiefintracornualer Besamung ipsilateral zur Seite des größten pröovulatorischen Follikels. Bei Einsatz deutlich reduzierter Spermienzahlen erscheint die rektal geleitete tief intracornuale Besamung hinsichtlich der Praktikabiltät für den Feldeinsatz besser geeignet, birgt aber im Vergleich zur hysteroskopischen Besamung ein höheres Risiko uteriner Traumatisierung. Andererseits bedarf die hysteroskopische Samenübertragung teurer Instrumentarien und erfahrener Operatoren. In Fällen vergrößerter Uteri und ausgeprägtem endometrialem Ödem (Fohlenrosse) gelingt die visuelle Darstellung der uterotubalen Verbindung gelegentlich nicht. Risiken 
hinsichtlich hygienischer Aspekte bei Einsatz tiefintrauteriner Besamungstechniken bedürfen weiterer Untersuchungen. Der Einsatz tiefintrauteriner Besamungstechniken bei Hengsten mit vorberichtlich herabgesetzten Fruchtbarkeitsraten wird in der Literatur kontrovers diskutiert und bedarf weiterer Untersuchungen hinsichtlich durch die Besamungstechnik potentiell kompensierbarer spermatologischer Parameter.

Schlüsselwörter: Besamung mit geringer Spermienzahl, Hengstsperma, hysteroskopische Samenübertragung, Spermiendosis, Fruchbarkeit

\section{Sperm number}

Commonly $500 \times 10^{6}$ progressively motile spermatozoa (pms) provide satisfactory pregnancy rates when mares are inseminated every other day during estrus (Pickett and Voss 1975). A dose of $50 \times 10^{6} \mathrm{pms}$ can be regarded as a critical sperm number for insemination with fresh semen as reported by Householder et al. (1981). The most commonly used dose is $500 \times 10^{6}$ pms with fresh semen, recommended by Pickett et al. (2000) for maximum reproductive efficiency. These authors suggested $1.000 \times 10^{6} \mathrm{pms}$ for cooled semen at the time when the semen is packaged prior to cooling, and 800 $\times 10^{6}$ total frozen spermatozoa with a post thaw pms percentage of at least $30 \%$. Others recommend insemination with $300 \times 10^{6}$ pms frozen/thawed spermatozoa (Leipold et al. 1998) close to ovulation or insemination daily until ovulation with a total of $400 \times 10^{6}$ frozen/thawed spermatozoa (Vidament et al. 1999). Although the minimum number of spermatozoa per insemination dose probably varies between stallions, the optimal amount required with frozen/ thawed spermatozoa has not yet been determined for the stallion.

Few studies exist that provide fertility data from a large number of mares inseminated with frozen/thawed semen. Müller (1987) reported in a five year survey (1981-1985) a $43 \%$ (414/959) first cycle pregnancy rate, when mares were inseminated with $300 \times 10^{6} \mathrm{pms}$ in an average of 2,2 times per cycle. Vidament et al. (1997) reported fertility rates between 32 and $41 \%$ (total of 1.473 cycles, 1991-1995) when mares were inseminated two or more times per cycle with a total of either $150 \times 10^{6}$ or $300 \times 10^{6} \mathrm{frozen} /$ thawed spermatozoa at $24 \mathrm{~h}$ intervals. From 1996 to 1999, a study using an increased $\mathrm{Al}$ dose of $400 \times 10^{6}$ frozen/thawed spermatozoa was carried out where the per cycle pregnancy rate was observed to be $49 \%$ (4190 cycles) (Vidament et al. 1999). The authors suggested that modifications in the technique for frozen/thawed semen in french National Studs (e.g. centrifugation and addition of freezing extender at $22^{\circ} \mathrm{C}$; Al with $400 \times 10^{6}$ spermatozoa/Al every $24 \mathrm{~h}$ before ovulation; more than one $\mathrm{Al}$ per cycle) were responsible for the improved fertility results being more equal to those from $\mathrm{Al}$ with fresh semen $(56 \%$, 2.050 cycles).

Minimal semen standard requirements for $\mathrm{Al}$ proposed by the World Breeding Federation of Sport Horses (WBFSH) are shown in Table 1. Fresh semen and chilled semen used within 12 hours after collection, should contain initially $300 \times 10^{6}$ pms with $\Delta 35 \% \mathrm{pms}$ at the time of insemination. Chilled semen inseminated within $24-36 \mathrm{~h}$ after collection should have $\Delta 35 \%$ pms at the time of insemination and should initially be diluted to $600 \times 10^{6} \mathrm{pms}$. The minimum requirements for frozen/thawed semen post-thawing are $250 \times 10^{6} \mathrm{pms}$ with $\Delta 35 \%$ pms. A breeding dose for insemination of one mare should contain a minimum of 3 insemination doses.
For frozen/-thawed semen, we found from our own studies that an insemination regime with a single insemination is sufficient when performed within $12 \mathrm{~h}$ before to $12 \mathrm{~h}$ after ovulation. For cooled semen the time interval for $\mathrm{Al}$ is a bit more brodened to $24 \mathrm{~h}$ before to $12 \mathrm{~h}$ after ovulation. "Re-insemination" $24 \mathrm{~h}$ later is recommended, if ovulation does not occur within the specified period after Al. The major beneficial effect of multiple inseminations per cycle on pregnancy rates seems to arise from the increased likelihood of Al within this optimal window but needs to be considered with the extra costs of semen or semen transportation (Sieme et al. 2003).

Tab 1 Minimum standard requirements for semen for Al published as proposals by the World Breeding Federation of Sport Horses (WBFSH)

Minimale Standardanforderungen für KB-Sperma veröffentlicht als Empfehlungen durch die World Breeding Federation of Sport Horses (WBFSH)

\begin{tabular}{|c|c|}
\hline \multicolumn{2}{|c|}{ Minimum standard requirements for semen for A.I. (WBFSH) } \\
\hline Fresh semen: & - minimum 300 million progressively motile sperm (pms) \\
\hline \multicolumn{2}{|l|}{ Chilled semen: } \\
\hline $\begin{array}{l}\text { diluted/fresh } \\
\text { sperm dose : }\end{array}$ & $\begin{array}{l}\text { - minimum of } 300 \text { pms at time of portioning } \\
\text { - insemination within } 12 \text { hours of collection } \\
\text { - storage conditions maintained } \\
\text { - pms at time of insemination not less than } 35 \%\end{array}$ \\
\hline $\begin{array}{l}\text { diluted/transportec } \\
\text { sperm dose: }\end{array}$ & $\begin{array}{l}\text { - minimum of } 600 \mathrm{pms} \text { at time of portioning } \\
\text { - maximum volume } 40 \mathrm{cc} \text { (dilution 1:2) } \\
\text { - insemination } 24-36 \text { hours after collection } \\
\text { - storage conditions maintained } \\
\text { - pms at time of insemination not less than } 35 \% \\
\text { - all semen leaving the AI-center has to be treated } \\
\text { as diluted/transport semen. }\end{array}$ \\
\hline \multicolumn{2}{|l|}{ Frozen semen: } \\
\hline $\begin{array}{l}\text { volume dose: } \\
\text { sperm dose: }\end{array}$ & $\begin{array}{l}\text { - dependent on manufacturing process } \\
\text { - minimum of } 35 \% \text { pms post-thawing } \\
\text { - mininimum of } 250 \text { million pms per A.I. dose post-thawing } \\
\text { - a breeding dose for insemination of one mare has to contain a } \\
\text { minimum of } 3 \text { insemination doses. } \\
\text { free to sell a single insemination dose }\end{array}$ \\
\hline
\end{tabular}

\section{Site/Techniques of insemination}

Site of sperm deposition

During natural mating and routine $\mathrm{Al}$, semen is deposited directly into the uterine body. This is acceptable when sufficient good quality semen is available. However, if low numbers of spermatozoa are available alternative techniques may be desired. To study the effects of insemination technique on distribution of spermatozoa in the equine genital tract, 12 estrous mares were inseminated into the uterine body and 15 estrous mares into the uterine horn, ipsilateral to the preovulatory follicle with frozen/thawed spermatozoa (Fêo et al. 1992). One to two hours after Al mares were slaughtered and portions of the uteri were clamped in order to obtain seg- 
ments of cervix, uterine body, uterine horns and oviducts. These segments were flushed and the number of spermatozoa in each was counted. Sperm numbers were significantly higher in the inseminated uterine horn as compared to the contralateral horn when intracornual inseminations was carried out. In addition, the number of spermatozoa in the inseminated uterine horn was significantly higher compared to both uterine horns when mares were inseminated in the uterine body. The authors concluded that this demonstrates the advantages of depositing semen closer to the site of ovulation.

Interstingly in the same study, the mean numbers of spermatozoa recovered in the right and left oviducts were not significantly different between uterine body and uterine horn inseminations. The site of uterine sperm deposition may not influence migration of spermatozoa into the oviduct.

In dairy cattle, site of semen deposition is discussed controversially. Senger et al. (1988) reported higher pregnancy rates for cornual inseminations compared to uterine body insemination, whereas McKenna et al. (1990) found no advantage using cornual insemination. Hawk et al. (1988) showed that insemination onto the infundibular surfaces of the cranial oviduct employing laparascopy reduced fertility significantly when compared to uterine body insemination ( $9 \%$ and $62 \%$ respectively). These findings suggested that exposure of spermatozoa to the uterus is important in achieving good fertility. In the same study semen was placed close to the UTJ after insertion of a flexible tube through the cervix. No difference was found in fertility when compared to uterine body insemination using either fresh or frozen/thawed semen. The authors suggested that in dairy cattle, the tendency for retrograde sperm transport is so strong that fertility is not higher even though semen is deposited much closer to the UTJ.

In equine $\mathrm{Al}$, it remains open whether the site of semen deposition in the uterus affects migration of spermatozoa in the oviduct and the time required for a competent number of viable spermatozoa to move into the caudal isthmus has to been taken into consideration. The majority of spermatozoa are eliminated from the uterus within $4 \mathrm{~h}$ after Al (Katila 1995). Scott et al. (1995) reported a selection at the oviductal epithelium, favouring motile and morphological normal spermatozoa. They also found that sperm transport takes 4 hours in the mare. This implies, sperm transport may not have been complete in the study of Fêo et al. (1992). However, it is still unkown, how much time sperm transport really takes. It may be that only 15 to 30 minutes are required.

\section{Insemination techniques}

Sex-selection before fertilization is now possible by means of high speed flowcytometry, which seperates spermatozoa into $X$ - and Y-chromosome bearing populations. However, limited number of spermatozoa being sorted per hour are insufficient for conventional insemination into the uterine body of mares. Therefore low dose insemination techniques were initially developed for the successful insemination of sex sorted spermatozoa (for review: Lindsey et al. 2001, Morris and Allen 2002). McCue et al. (2000) produced pregnancies by oviductal insemination with only $5 \times 10^{4} \mathrm{pms}$, but this method is impractical as it requires laparatomy. Deep uterine insemina- tion has been reported employing a flexible catheter that is inserted in the uterine horn ipsilateral to the preovulatory follicle. The position of the catheter can be verified either by ultrasonography (Buchanan et al. 2000) or by transrectal palpation of the uterotubal papilla (Woods et al. 2000, Rigby et al. 2001). The hysteroscopic insemination - depositing semen onto the UTJ papilla using a videoendoscope - seems to produce acceptable pregnancy results with a small numbers of spermatozoa as previously reported by Vasquez et al. (1998), Manning et al. (1998), Morris et al. (2000).

Some literature report similar or even better results when semen was transfered to the uterine horn with the use of either a rectally guided insemination gun or by hysteroscopic insemination instead of routine insemination into the uterine body (Féo et al. (1992), Woods et al. (2000), Morris et al. (2000a), Alvaraenga and Leào 2002, Petersen et al. 2002). On the other hand Manning et al. (1998), Buchanan et al. (2000), McCue et al. (2000) and Squires et al. (2002) reported an opposite effect of the two insemination techniques on pregnancy rates of mares. These conflicting reports make it difficult to draw conclusions for Al practice and suggest that some essential factors varying between studies (e.g. sperm dose, sort of spermatozoa, technique of hysteroscopic insemination) have to be considered carefully (Tab. 2).

Intrauterine treatment with prostaglandin E2 prior to low dose (5 × $10^{6} \mathrm{pms}$ cooled/stored) transrectally-guided or hysteroscopic-guided deep intrauterine insemination in order to influence oviductal smooth muscle function and subsequent oviductal sperm migration has not been shown to result in increased pregnancies in the mare (Brinsko et al. 2003).

The use of low dose insemination techniques with frozen/thawed stallion semen however, may increase pregnancy rates. Al with frozen/thawed semen commonly produces lower conception rates as compared to $\mathrm{Al}$ with fresh or chilled stallion semen (Pickett et al. 2000). It is generally accepted that freezing causes semen damage and lowers the chances for pregnancy to spermatozoa (Watson 2001). Furthermore, the removal of seminal plasma related to the dilution of the ejaculates based on sperm numbers as well as centrifugation is disadvantageous. Studies suggest that seminal plasma helps to protect spermatozoa to facilitate optimal transport conditions in the genital tract (Kotilainen et al. 1994, Troedsson et al. 2002).

Deposition of spermatozoa close to the UTJ may increase the number of viable spermatozoa which reach the oviduct. In the literature the requirement of rectally or ultrasonographically guided intracornual or hysteroscopic techniques of low insemination dosages is another controversially discussed issue. In comparison to uterine body insemination, Petersen et al. (2002) observed no differences in embryo recovery rates when mares were inseminated twice $112 \mathrm{~h}$ and $36 \mathrm{~h}$ after hCG-administration) with only $50 \times 10^{6} \mathrm{pms}$ frozen/thawed spermatozoa inseminated deep into the uterine horn, ipsilateral to the pre-ovulatory follicle in comparison to semen doses of $500 \times 10^{6}$ pms fresh semen inseminated into the uterine body $12 \mathrm{~h}$ after hCG treatment and $500 \times 10^{6} \mathrm{pms}$ cooled-stored spermatozoa $36 \mathrm{~h}$ after hCG $(7 / 11,64 \%$ vs $4 / 11$, $34 \%)$. As comapared to uterine body insemination, Squires et al. (2002) reported lower pregnancy rates when mares were 
Tab 2 Overview: low dose insemination techniques in the mare Übersicht zu Besamungstechniken mit geringer Spermienzahl bei der Stute

\begin{tabular}{|c|c|c|c|c|c|c|}
\hline Reference & $\begin{array}{l}\text { AI } \\
\text { tech- } \\
\text { nique }\end{array}$ & $\begin{array}{l}\text { Type of } \\
\text { sperm }\end{array}$ & $\begin{array}{l}\text { Number of } \\
\text { sperm } \\
\left(\times 10^{6}\right)\end{array}$ & $\begin{array}{l}\text { Inseminate } \\
\text { volume } \\
\text { (ml) }\end{array}$ & $\begin{array}{l}\text { Pregnancy } \\
\text { rate }\end{array}$ & $(\%)$ \\
\hline Feo et al. (1992) & $\begin{array}{l}\mathrm{ub} \\
\mathrm{uh}\end{array}$ & frozen & $250-350$ & 4 & $\begin{array}{l}8 / 25 \\
32 / 48\end{array}$ & $\begin{array}{l}32 \\
66\end{array}$ \\
\hline $\begin{array}{l}\text { Manning et al. } \\
\text { (1998) }\end{array}$ & $\begin{array}{l}\text { ub } \\
\text { ub } \\
\text { hs } \\
\text { hs }\end{array}$ & fresh & $\begin{array}{l}100 \mathrm{pms} \\
10 \mathrm{pms} \\
10 \mathrm{pms} \\
1 \mathrm{pms}\end{array}$ & $\begin{array}{l}<12 \\
2.5 \\
0.25 \\
<0.16\end{array}$ & $\begin{array}{l}4 / 12 \\
2 / 12 \\
0 / 11 \\
2 / 9\end{array}$ & $\begin{array}{l}33 \\
17 \\
0 \\
22\end{array}$ \\
\hline $\begin{array}{l}\text { Vazquez et al. } \\
\text { (1998) }\end{array}$ & hs & fresh & $3.8 \mathrm{pms}$ & 0.2 & $3 / 10$ & 33 \\
\hline $\begin{array}{l}\text { Buchanan et al. } \\
\text { (2000) }\end{array}$ & $\begin{array}{l}\text { ub } \\
\text { uh } \\
\text { uh }\end{array}$ & fresh & $\begin{array}{l}500 \mathrm{pms} \\
25 \mathrm{pms} \\
5 \mathrm{pms}\end{array}$ & $\begin{array}{l}20 \\
1 \\
0.2-1 \\
\end{array}$ & $\begin{array}{l}18 / 20 \\
12 / 21 \\
7 / 20 \\
\end{array}$ & $\begin{array}{l}90 \\
57 \\
35\end{array}$ \\
\hline Woods et al. (2000) & $\begin{array}{l}\text { ub } \\
\text { uh }\end{array}$ & fresh & 25 & 1 & $\begin{array}{l}10 / 18 \\
10 / 16\end{array}$ & $\begin{array}{l}56 \\
63 \\
\end{array}$ \\
\hline McCue et al. (2000) & $\begin{array}{l}\text { ub } \\
\text { surg. }\end{array}$ & fresh & $\begin{array}{l}500 \mathrm{pms} \\
0.05 \mathrm{pms}\end{array}$ & $\begin{array}{l}20 \\
0.05\end{array}$ & $\begin{array}{l}6 / 15 \\
3 / 14\end{array}$ & $\begin{array}{l}40 \\
21\end{array}$ \\
\hline Morris et al. (2000) & hs & fresh & $\begin{array}{l}10 \\
5 \\
1 \\
0.5 \\
0.1 \\
0.001\end{array}$ & $0.03-0.15$ & $\begin{array}{l}6 / 10 \\
6 / 8 \\
16 / 25 \\
4 / 14 \\
? / 11 \\
1 / 10\end{array}$ & $\begin{array}{l}60 \\
75 \\
64 \\
29 \\
22 \\
10\end{array}$ \\
\hline $\begin{array}{l}\text { Morris et al. } \\
(2000 b)\end{array}$ & $\begin{array}{l}\mathrm{hs} \\
\mathrm{ub} \\
\mathrm{hs} \\
\mathrm{ub}\end{array}$ & frozen & $\begin{array}{l}25 \mathrm{pms} \\
5 \mathrm{pms}\end{array}$ & $\begin{array}{l}0.5 \\
0.1\end{array}$ & $\begin{array}{l}9 / 14 \\
9 / 12 \\
16 / 34 \\
2 / 8 \\
\end{array}$ & $\begin{array}{l}64 \\
75 \\
47 \\
25 \\
\end{array}$ \\
\hline $\begin{array}{l}\text { Rigby et al. } \\
\text { (2000) }\end{array}$ & $\begin{array}{l}\text { uh } \\
\text { hs }\end{array}$ & fresh & 5 & 0.2 & $\begin{array}{l}10 / 20 \\
13 / 21\end{array}$ & $\begin{array}{l}50 \\
62 \\
\end{array}$ \\
\hline $\begin{array}{l}\text { Alvarenga et al. } \\
\text { (2001) }\end{array}$ & hs & frozen & $100-150$ & $2 \times 0.5$ & $\begin{array}{l}12 / 22 \text { centre } \mathrm{A} \\
22 / 40 \text { centre } \mathrm{B}\end{array}$ & $\begin{array}{l}54 \\
52\end{array}$ \\
\hline $\begin{array}{l}\text { Alvarenga and } \\
\text { Leao (2002) }\end{array}$ & $\begin{array}{l}\text { hs } \\
\text { hs } \\
\text { ub }\end{array}$ & frozen & $\begin{array}{l}10 \mathrm{pms} \\
10 \mathrm{pms} \\
400 \mathrm{pms}\end{array}$ & Percoll & $\begin{array}{l}4 / 12 \\
4 / 12 \\
0 / 12\end{array}$ & $\begin{array}{l}33 \\
33 \\
0\end{array}$ \\
\hline $\begin{array}{l}\text { Petersen et al. } \\
(2000)\end{array}$ & $\begin{array}{l}\text { uh } \\
\text { ub }\end{array}$ & $\begin{array}{l}\text { frozen } \\
\text { fresh }\end{array}$ & $\begin{array}{l}50 \mathrm{pms} \\
500 \mathrm{pms}\end{array}$ & $\begin{array}{l}0.5(2 \mathrm{AI}) \\
(2 \mathrm{AI})\end{array}$ & $\begin{array}{l}7 / 11 \\
4 / 11\end{array}$ & $\begin{array}{l}64 \\
37 \\
\end{array}$ \\
\hline $\begin{array}{l}\text { Squires et al. } \\
\text { (2002) }\end{array}$ & $\begin{array}{l}\text { ub } \\
\text { ub } \\
\text { ub } \\
\text { uh }\end{array}$ & frozen & $\begin{array}{l}800 \\
400 \\
200 \\
200\end{array}$ & $\begin{array}{l}2(1 \mathrm{AI}) \\
1(2 \mathrm{AI}) \\
0.5(2 \mathrm{AI}) \\
0.5(2 \mathrm{AI}))\end{array}$ & $\begin{array}{l}12 / 20 \\
11 / 20 \\
10 / 20 \\
4 / 20\end{array}$ & $\begin{array}{l}60 \\
55 \\
50 \\
20\end{array}$ \\
\hline Ismer (2002) & $\begin{array}{l}\text { ub } \\
\text { hs } \\
\text { ub } \\
\text { hs } \\
\text { ub } \\
\text { hs } \\
\end{array}$ & $\begin{array}{l}\text { stallion A } \\
\text { stallion B } \\
\text { stallion C }\end{array}$ & $\begin{array}{l}500 \mathrm{pms} \\
6,12,80 \\
500 \mathrm{pms} \\
100 \\
500 \mathrm{pms} \\
100-200\end{array}$ & $\begin{array}{l}10-20 \\
0.2-1.6 \\
10-20 \\
5 \\
10-20 \\
10-20\end{array}$ & $\begin{array}{l}49 / 86 \\
32 / 108 \\
214 / 305 \\
9 / 20 \\
3 / 8 \\
37 / 68 \\
\end{array}$ & $\begin{array}{l}57 \\
29 \\
70 \\
45 \\
37 \\
55\end{array}$ \\
\hline $\begin{array}{l}\text { Brinsko et al. } \\
\text { (2003) }\end{array}$ & $\begin{array}{l}\text { hs } \\
\text { hs } \\
\text { uh } \\
\text { uh }\end{array}$ & cooled & $5 \mathrm{pms}$ & $\begin{array}{l}0.2+\text { PGE } \\
0.2+\text { saline } \\
0.2+\text { PGE } \\
0.2+\text { saline }\end{array}$ & $\begin{array}{l}6 / 9 \\
6 / 9 \\
5 / 9 \\
5 / 9 \\
\end{array}$ & $\begin{array}{l}67 \\
67 \\
56 \\
56\end{array}$ \\
\hline Morris et al. (2003) & $\begin{array}{l}\text { ub } \\
\text { hs } \\
\text { hs } \\
\text { ub } \\
\text { hs }\end{array}$ & frozen & $\begin{array}{l}14 \mathrm{pms} \\
14 \mathrm{pms} \\
3 \mathrm{pms} \\
3 \mathrm{pms} \\
3 \mathrm{pms}\end{array}$ & $\begin{array}{l}0.5 \\
0.5 \\
0.1 \\
0.1 \\
0.1 \text { contral. }\end{array}$ & $\begin{array}{l}8 / 12 \\
9 / 14 \\
16 / 34 \\
2 / 14 \\
1 / 12\end{array}$ & $\begin{array}{l}67 \\
64 \\
47 \\
14 \\
8\end{array}$ \\
\hline
\end{tabular}

$u b=$ routine insemination into the uterine body

$u h=$ rectally controlled deep intrauterine insemination close to the utereotubal junction ipsilateral to the preovulatory folli cle

hs $=$ hysteroscopic-guided deep intrauterine insemination onto the uterotubal junction ipsilateral to the preovulatory follicle

inseminated with only $200 \times 10^{6}$ frozen/thawed spermatozoa deep into the uterine horn, ipsilateral to the pre-ovulatory follicle $(4 / 20,20 \%$ vs $10 / 20,50 \%)$. In contrast, Morris et al. (2000b) observed that hysteroscopic uterotubal insemination with $25 \times 10^{6} \mathrm{pms}$ frozen/thawed spermatozoa hold no advantage over uterine body insemination $(9 / 14,64 \%$ vs $9 / 12,75 \%)$. When the same authors used only $5 \times 10^{6} \mathrm{pms}$ frozen/thawed spermatozoa, hysteroscopic insemination on the UTJ showed better results than when semen was deposited cranial to the cervix by means of a videoendoscope $(16 / 34,47 \%$ vs $2 / 8,25 \%)$. In a further experiment Morris et al. (2003) observed significantly higher pregnancy rates when mares were inseminated with $3 \times 10^{6} \mathrm{pms}$ frozen/thawed spermatozoa hysteroscopically compared to uterine body insemination $(16 / 34,47 \%$ vs $2 / 14,14 \%)$. In the same study one of 12 mares became pregnant after hysteroscopic insemination of $3 \times 10^{6} \mathrm{pms}$ frozen/thawed spermatozoa onto the
UTJ contralateral to the preovulatory follicle, thus, retrograde sperm transport may play a role in the mare. Alvarenga and Leào (2002) found no significant difference between conception rates of mares inseminated with either $10 \times 10^{6}$ pms frozen/thawed spermatozoa hysteroscopically onto the UTJ, 10 $x 10^{6} \mathrm{pms}$ of frozen/thawed and Percoll selected spermatozoa hysteroscopically onto the UTJ or $400 \times 10^{6}$ pms into the uterine body (4/12, 33.3\%; 4/12, 33.3\%; 0/12, 0\%). The collective results from hysteroscopic insemination (both with and without Percoll selection) were significantly higher than after uterine body insemination. Lindsey et al. (2002a) observed lower pregnancy rates using $5 \times 10^{6}$ frozen/thawed sorted spermatozoa by hysteroscopic insemination, (2/15, $13.3 \%$ ) as compared to frozen/thawed unsorted spermatozoa $(6 / 16,37.5 \%)$. Despite the use of low numbers of mares used in the described studies, the results indicate that deep intrauterine, low dose insemination of frozen/thawed spermatozoa may achieve reasonable pregnancy rates. Alvarenga et al. (2001) inseminated mares hysteroscopically within 6 hours on the side of ovulation with two $0.5 \mathrm{ml}$ straws, each containing $50-75 \times 10^{6}$ spermatozoa with at least $30 \%$ postthaw motility at two different $\mathrm{Al}$-centres. The pregnancy rates were $54.5 \%(12 / 22)$ and $52.5 \%$ (22/40) for center A and B respectively. Unfortunately in the latter study no control inseminations were reported.

The weighted mean of pregnancy rates of all the studies listed in Table 2 when frozen/thawed semen was transfered by either rectally controlled deep intrauterine insemination into the uterine horn ipsilateral to the preovulatory follicle (uh) or by hysteroscopic insemination (hs) were 54.4\%; (43/79) and $50.5 \%$; $92 / 182)$. Pregnancy rates after Al with fresh or cooled semen after uh insemination were $51.5 \%$ (49/95) and $41.9 \%$ (144/343) after hs insemination

The concentration of semen has been shown to effect pregnancy rate as well. Jasko et al. (1992) reported a decrease in pregnancy rates when the sperm number of fresh stallion spermatozoa was below $25 \times 10^{6}$ pms. When frozen/-thawed semen was used, inseminate volume and total sperm number also effect pregnancy rate as shown in a multi-center study by Samper et al. (2002). Others produced pregnancies with low doses and small seminal plasma volumes employing hysteroscopic, uterotubal inseminations (Morris et al. 2000, Alvarenga et al. 2001), or rectally guided deep intracornual insemination (Petersen et al. 2002)

It seems questionable, whether such low sperm doses are really needed with respect to studfarm practice, bearing in mind that stallions produce approximately 5.0 to $7.0 \times 10^{9}$ spermatozoa per ejaculate (Pickett et al. 1987). As long as $50 \%$ of spermatozoa are progressively motile and using a standard dose of $50 \times 10^{6}$ pms cooled spermatozoa, 50 to 70 mares can be inseminated from a single ejaculate. This is plenty to cover the demand of semen from top stallions, possibly without the use of hysteroscopic or deep intauterine insemination techniques which require skilled experience of the inseminator. Consequently, the main application of deep intrauterine hysteroscopic insemination will for a foreseeable time be Al with sex sorted spermatozoa, either stored or frozen/thawed as reported by Lindsey et al. (2002 a,b,c).

Before extensive use of these different insemination techniques, some aspects of studfarm practice must have been taken into consideration. Firstly, payment policy, prices of 
individual frozen/thawed semen doses and prices for veterinary services determine, which insemination method is economically the best. If the price is based on insemination doses with frozen/thawed semen, only one insemination per oestrus can often be afforded. Generally, a single insemination dose of frozen/thawed stallion spermatozoa is packaged in 4 to 8 x $0.5 \mathrm{ml}$ straws (Samper et al. 2002). The frozen/thawed sperm dose recommended in many reports (Leipold et al. 1998, Vidament et al. 1999, Samper et al. 2002) could obviously been reduced without risking a decrease in fertility as demonstrated in the studies of Morris et al. (2001), Alvarenga et al. (2001) and Petersen et al. (2002).

Another aspect of hysteroscopic insemination using semen from stallions with low fertility is currently discussed contraversial. Morris and Allen (2002) summarized that use of hysteroscopic insemination with low numbers of spermatozoa from infertile stallions does not improve their fertility. In contrast, Koene et al. (2002) and Ismer (2002) observed a significant increase in pregnancy rates when mares were inseminated hysteroscopically $(37 / 68,55.2 \%)$ instead of with conventional $\mathrm{Al}(3 / 8,37.5 \%)$ into the uterine body with semen from one particular stallion. The stallion showed asthenozoospermy and a history of reduced fertility. However, in the same study the authors reported a significant reduction in pregnancy rates from hysterscopic insemination vs uterine body $\mathrm{Al}$ when semen of two normospermic stallions was used (stallion A: $32 / 108,29.6 \%$ vs 49/86, 57.0\%; stallion B: 9/20, $45.0 \%$ vs $204 / 305,70.2 \%)$. Further studies are required to discover which specific sperm defects may be compensated by different insemination sites/techniques.

Furthermore, it is evident that inseminations in mares are followed by post breeding endometritis (for review: Katila 2001, Troedsson et al. 2001). Therefore one may suggest the use of of lower numbers and volumes of sperm directly on the uterotubal papilla reduce risk of post breeding endometrits (Lindsey et al. 2001). However, Schiemann et al. (2001) detected in 4 out of 8 healthy diestrous mares pathogenic microbes ( 3 $x$ Pseudomonas aeruginosa, 1 x b-hem. Streptococcus), five days after diagnostic hysteroscopy. Six mares showed inflammatory endometrial reaction and a remarkable eosinophilia as detected in histological preparations of endometrial biopsies. The same authors recommend a follow up treatment for mares undergoing hysteroscopy and speculated that etiology of eosinophilia was induced by distension of the uterus with air. Further studies are required to determine hygienic risks of hysteroscopic inseminations in problematic mares, as previously suggested by Squires et al. (2002).

During the breeding season 2002, our group investigated the effect of different insemination techniques on twin pregnancy rates in mares that had double-ovulation either ipsilateral or contaralateral. Hanoverian warmblood mares were inseminated once per cycle, $24 \mathrm{~h}$ after hCG administration with cooled semen, and alternatively $30 \mathrm{~h}$ after hCG with frozen/thawed semen. Mares were placed randomly into groups, each inseminated with a different technique [i.e., routine insemination into the uterine body (ub) and deep into the uterine horn (uh) ipsilateral to the preovulatory follicle the latter either rectally controlled or hysteroscopically]. Differences in fertility results between treatment groups were analysed by Chi-squared test using the SAS statistics package. Images of the UTJ of some of the mares inseminated with the help of a videoendoscope are presented in Figure 1. Out of the 331 mares, double ovulation was detected in 35 (10.6\%) 19 ipsilateral and 16 contralateral. Pregnancy rates were similar after $u b$ or uh insemination insemination. Twin pregnancy rates were not different in mares inseminated into the uterine

Fig 1 Hysteroscopic view onto the uterotubal junction showing the uterine papilla ipsilateral to the preovulatory follicle of an estrous mare (a). Presence of bubbles after deposition of low number of sperm suspended in a small inseminate volume (b). Distribution and reflux of semen after hysteroscopic insemination of a commercial inseminate volume $(\sim 12 \mathrm{ml})$ (c)

Hysteroskopische Darstellung der Uterotubalpapille ipsilateral zum präovulatorischen Follikel einer östrischen Stute (a). Adhäsion eines geringvolumigen Inseminats an der Uterotubalpapille mit Bläschenbildung (b). Verteilung und Reflux des Inseminats nach hysteroskopischer Insemination eines kommerziell üblichen Inseminationsvolumens $(\sim 12 \mathrm{ml})$ (c)
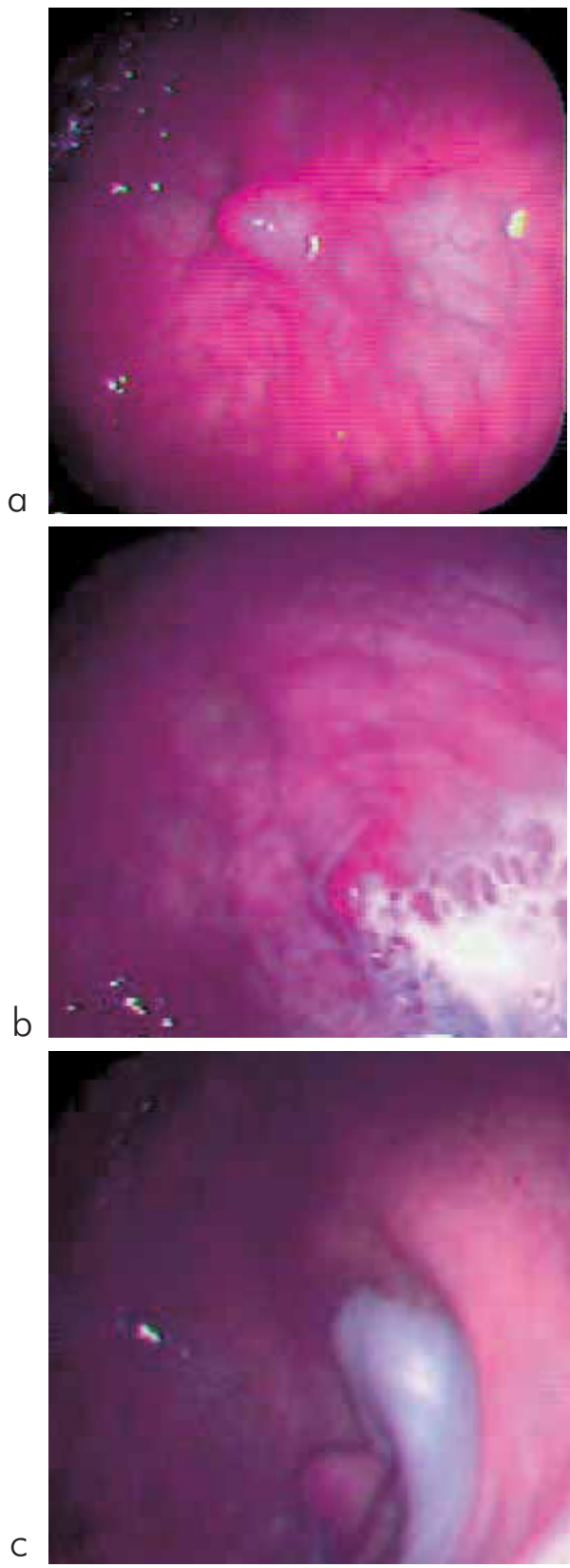

body after either ipsilateral or contralateral double ovulation; whereas after deep intrauterine insemination into the uterine horn twin pregnancy rate were significantly reduced when double ovulations occured contralateral (Table 3). 
Tab. 3 Twin pregnancy rates after routine insemination into the uterine body (ub) and inseminations deep into the uterine horn (uh, either rectally controlled or hysteroscopically) with respect to side of double ovulation (ipsilateral, contralateral) in warmblood mares.

Zwillingsträchtigkeitsraten nach Routine-Samenübertragung in den Gebärmutterkörper (ub) und tiefintracornualer Besamung (uh, entweder rektal geleitet oder hysteroskopisch) unter Berükksichtigung ipsi- oder contralateraler Doppelovulationen bei Warmblutstuten.

\begin{tabular}{|c|c|c|c|c|c|c|c|c|c|c|}
\hline \multirow[t]{2}{*}{ Group } & \multicolumn{2}{|c|}{ Mares } & \multicolumn{2}{|c|}{$\begin{array}{l}\text { Pregnancy } \\
\text { ipsilateral }\end{array}$} & \multicolumn{2}{|c|}{$\begin{array}{c}\text { Pregnancy } \\
\text { contralateral }\end{array}$} & \multicolumn{2}{|c|}{$\begin{array}{c}\text { Twins } \\
\text { ipsilateral }\end{array}$} & \multicolumn{2}{|c|}{$\begin{array}{c}\text { Twins } \\
\text { contralateral }\end{array}$} \\
\hline & $(\mathrm{m} / \mathrm{n})$ & $\%$ & $(\mathrm{~m} / \mathrm{n})$ & $\%$ & $(\mathrm{~m} / \mathrm{n})$ & $\%$ & $(\mathrm{~m} / \mathrm{n})$ & $\%$ & $(\mathrm{~m} / \mathrm{n})$ & $\%$ \\
\hline$\Sigma \mathrm{ub}$ & $71 / 139$ & 51.1 & $5 / 10$ & 50.0 & $4 / 6$ & 66.6 & $2 / 10$ & 20 & $2 / 6$ & 33.3 \\
\hline$\Sigma$ uh & $101 / 192$ & 52.6 & $5 / 9$ & 55.5 & $7 / 10$ & 70.0 & $4 / 9$ & $44.4^{1}$ & $0 / 10$ & $0^{2}$ \\
\hline $\begin{array}{l}\Sigma \mathrm{ub}+\Sigma \\
\mathrm{uh}\end{array}$ & $172 / 331$ & 52 & $10 / 19$ & 52.6 & $11 / 16$ & 68.7 & $6 / 19$ & 31.6 & $2 / 16$ & 12.5 \\
\hline
\end{tabular}

$(\mathrm{m} / \mathrm{n})=$ number of pregnant mares $(\mathrm{m})$ out of total number of mares inseminated (n)

$\%=$ percentage of pregnant mares

$u b=$ routine insemination into the uterine body

uh $=$ deep insemination into the uterine horn (either rectally controlled or hysteroscopically)

pregnancy ipsilateral $=$ pregnancy rates in mares with ipsilateral double ovulations

pregnancy contralateral = pregnancy rates in mares with contralateral double ovulations

twins ipsilateral $=$ twin-pregnancy rates in mares with ipsilateral double ovulations

twins contralateral = twin-pregnancy rates in mares with ipsilateral double ovulations

$1: 2 p<0,05$

These data suggest that the incidence of twin pregnancy rates after contralateral double ovulations could possibly be reduced by the technique of insemination. Nevertheless, the authors do not recommend deep intrauterine insemination to reduce incidence of twin pregnancies in general for studfarm practice, especially as double ovulations increase the chances of pregnancy. The method of choice in managing equine twins in the mare is still early transrectal ultrasonographic detection of twins and manual crush of one embryonic vesicle as previously reported by Macpherson and Reimer (2000).

\section{Literature}

Alvarenga M. A. und Leào K. M. (2002): Hysteroscopic insemination of mares with low number of frozen thawed spermatozoa selected by percoll gradient. Theriogenology 58, 651-653

Alvarenga M. A., Onoe E., Fonseca H., Trinque C. L., Lima M. M. and Pinheiro L. P. L. (2001): Utilization of endoscopic insemination for the application of stallion frozen semen. XIV Congresso Brasileiro de Reproducao Animal. Belo Horizonte, Brazil, 1-5 August, 2001. Revista-Brasileira-de-Reproducao-Animal, 25, 361-362

Buchanan B. R., Seidel G. E., McCue P. M., Schenk J. L., Herickhoff L. A. and Squires E. L. (2000): Insemination of mares with low numbers of either unsexed or sexed spermatozoa. Theriogenology 53, 1333-1344

Brinsko S. P., Rigby S. L., Lindsey A. C., Blanchard T. L., Love C. C. and Varner D. D. (2003): Pregnancy rates in mares following hysteroscopic or transrectally-guided insemination with low sperm numbers at the utero-tubal papilla. Theriogenology 59, 1001 1009
Féo J. C. S. A., Oba E., Baranabe R. C. and Basile J. R. (1992): Artificial insemination in the equine: Distribution of spermatozoa in the genital tract: A comparison of mares inseminated in the uterine body and the uterine horn ipsilateral to the ovulatory follicle. 12th International Congress on animal reproduction, The Hague, The Netherlands, Congress Proc. Vol. 3, 1545-1547

Hawk H. W., Conley H. H., Wall R. J. and Whitaker R. O. (1988): Fertilization rates in superovulating cows after deposition of semen on the infundibulum, near the uterotubal junction or after insemination with high numbers of sperm. Theriogenology 29, 1131-1142

Householder D. D., Pickett B. W., Voss J. L. and Olar T. T. (1981): Effect of extender, number of spermatozoa, and HCG on equine fertility. J Equine Vet Sci 1, 9-13

Ismer N. N. (2002): Clinical investigation on the endoscopically controlled artificial insemination of warmblood mares under field conditions. Veterinary School Hanover, Thesis

Jasko D. J., Moran D. M., Farlin M. E., Squires E. L., Amann R. P. and Pickett B. W. (1992): Pregnancy rates utilizing fresh, cooled and frozen/thawed stallion semen. Proc 38th Am Assoc Equine Pract, 649-660

Katila T. (2001): Sperm-uterine interactions: a review. Anim Repro Sci 68, 267-272

Katila T. (1995): Onset and duration of uterine inflammatory response of mares after insemination with fresh semen. Biol Reprod Mono 1, 515-517

Koene M., Ismer N., Swagemakers J. H., Bader H. and Meinecke B. (2002): Video endoscopic inseminations in broodmares - First results. Pferdeheilkunde 18, 165-168

Kotilainen T., Huhtinen M. and Katila T. (1994): Sperm induced leucocytosis in the equine uterus. Theriogenology 41, 629-636

Leipold S. D., Graham J. K., Squires E. L., McCue P. M., Brinsko S. P. and Vanderwall D. K. (1998): Effect of spermatozoal concentration and number on fertility of frozen equine semen. Theriogenology $49,1537-1543$

Lindsey A. C., Bruemmer J. E. and Squires E. L. (2001): Low dose insemination of mares using non-sorted and sex-sorted sperm. Anim Reprod Sci 68, 279-289

Lindsey A. C., Morris L. H. A., Allen W. R., Schenk J. L., Squires E. L. and Brvemmer J. E. (2002a): Hysteroscopic insemination of mares with low numbers of nonsorted or flow sorted spermatozoa. Equine vet. J. 34, 128-132

Lindsey A. C., Schenk J. L., Graham J. K., Bruemmer J. E. and Squires E. L. (2002c): Hysteroscopic insemination of low numbers of flow sorted and frozen/thawed stallion spermatozoa. Equine vet. J. $34,121-127$

Lindsey A. C., Varner D. D., Seidel G. E., Bruemmer J. E. and Squires E. L. (2002b): Hysteroscopic or rectally guided, deep-uterine insemination of mares with spermatozoa stored $18 \mathrm{~h}$ at either 5 or $15{ }^{\circ} \mathrm{C}$ prior to flow-cytometric sorting. Theriogenology 58, 659662

Macpherson M. L. and Reimer J. M. (2000): Twin reduction in the mare: current options. Anim Repro Sci 60-61, 233-244

Manning S. T., Bowmann P. A., Fraser L. M. and Card C. L. (1998): Development of hysteroscopic insemination of the uterin tube in the mare. Proceeding for Annual Meeting Dec. 4-6, 1998 in Baltimore, Maryland, Society for Theriogenology, 84-85

McCue P. M., Fleury J. J., Denniston D. J., Graham J. K. and Squires E. L. (2000): Oviductal insemination of mares. Reprod., Suppl. 56, 499-502

McKenna T., Lenz R. W., Fenton S. E. and Ax R. L. (1990): Nonreturn rtaes of dairy cattle following uterine body or cornual insemination. J Dairy Sci 73, $1179-1183$

Morris L. H. A., Tiplady C. and Allen W. R. (2003): Pregnancy rates in mares after a single fixed time hysteroscopic inseminatioun of low numbers of frozen-thawed spermatozoa onto the the uterotubal junction. Equi Vet J 35, 197-201

Morris L. H. A. and Allen W. R. (2002): An overview of low dose insemination in the mare. Reprod Dom Anim 37, 206-210

Morris L. H. A. , Hunter R. H. F. and Allen W. R. (2000): Hysterosco- 
pic insemination of small numbers of spermatozoa at the uterotubal junction of preovulatory mares. J. Reprod. Fert. 118, 95-100

Morris L. H. A., Tiplady C., Wilsher S. and Allen W. R. (2000b): Hysteroscopic insemination of mares with low numbers of frozen/thawed ejaculated and epididymal spermatozoa. In: Proc 5th Int Symp on Equine Embryo Transfer. Havemeyer Foundation Monograph Series 3, 4-6

Müller Z. (1987): Practicalities of insemination of mares with deepfrozen semen. J Reprod Fertil Suppl 35, 121-125

Petersen M. M., Wessel M. T., Scott M. A., Liu I. K. M. and Ball B. A. (2002): Embryo recovery rates in mares after deep intrauterine insemination with low numbers of cryopreserved equine spermatozoa. Theriogenology 58, 663-665

Pickett B. W., Squires E. .L and McKinnon A. O. (1987): Procedures for collection, evaluation utilization of stallion semen for artificial insemination. CSU, Anim Reprod lab, Bull. No 3, Fort Collins, Colorado, 47

Pickett B. W., Voss J. L., Squires E. L., Vanderwall D. K., McCue P. M. and Bruemmer J. E. (2000): Collection, preparation and insemination of stallion semen. Anim Reprod Biotechn Lab, Bull. No 10, Fort Collins, Colorado, 94-95

Pickett B. W. and Voss J. L. (1975): The effect of semen extenders and sperm number on mare fertility. J Reprod Fertil Suppl 23, 95 98

Rigby S. L., Lindsey A. C., Brinsko S. P., Blanchard T. L., Love C. C. and Varner D. D. (2001): Pregnancyrates in mares following hysteroscopic or rectally-guided utero-tubal insemination with low sperm numbers. Proceedings of $3^{\text {rd }}$ International Symposium on Stallion Reprod., Fort Collins, CO, 49 (abstr.)

Samper J. C., Vidament M., Katila T., Newcombe J., Estrada A. and Sargeant J. (2002): Analysis of some factors associated with pregnancy rates of frozen semen: a multi-center study. Theriogenology 58, 647-650

Schiemann V., Bartmann C. P., Kirpal G., von Reiswitz A., Schoon HA. and Klug E. (2001): Diagnostic hysteroscopy in the mare - uterine contamination and endometrial reaction. Pferdeheilkunde 6, 557-564

Scott M. A., Liu I. K. M. and Overstreet J. W. (1995): Sperm transport to the oviducts: abnormalities and their clinical implications. $41 \mathrm{st}$ Ann. AAEP Convent. Proc., Lexington, Kentucky (Dec.3-6, 1995), Vol. 41, 1-2
Senger P. L., Becker W. C. and Hillers J. K. (1988): Influence of cornual insemination on conception rates in dairy cattle. J Anim Sci $66,3010-3016$

Sieme H., Schäfer T., Stout T. A. E., Klug E. and Waberski D. (2003): The effects of different insemination regimes on fertility in mares. Theriogenology, in press

Squires E. L., Reger H. P., MaCLellan L. J. and Bruemmer J. E. (2002): Effect of time of insemination and site of insemination on pregnancy rates with frozen semen. Theriogenology 58, 655-658

Troedsson M. H. T., Alghamdi A. S. and Mattisen J. (2002): Equine seminal plasma protects the fertility of spermatozoa in an inflamed uterine environment. Theriogenology 58, 453-456

Troedssson M. H. T., Loset K., Alghamdi A. M., Dahms B. and Crabo B. G. (2001): Interaction between equine semen and the endometrium: the inflammatory response to semen. Animal Reproduction Science 68, 273-278

Vazquez J. J., Medina V., Liu I. K., Ball B. A. and Scott M. A. (1998): Nonsurgical uterotubal insemination in the mare. Proceedings for Annual Meeting Dec. 4-6, 1998 in Baltimore, Maryland from the Society for Theriogenology, 82-83

Vidament M., Dupère A. M., Julienne P., Evain A., Noue P. and Palmer E. (1997): Equine frozen semen freezability and fertility field results. Theriogenology 48, 905-917.

Vidament M., Magistrini M., Palmer E. and Clement F. (1999): Equine artificial insemination in French National Studs. Reprod Dom Anim Suppl 6, 61-66.

Watson P. F. (2000): The causes of reduced fertility in cryopreserved semen. Anim Reprod Sci 60-61, 481-492

Woods J., Rigby S., Brinsko S., Stephens R., Varner D. and Blanchard T. (2000): Effect of intrauterine treatment with prostaglandin E2 prior to insemination of mares in the uterine horn or body. Theriogenology 53, 1827-1836

Dr. Harald Sieme

Nieders. Landgestuet Celle

Spoerckenstr. 10

29221 Celle

Germany

stallions.celle@t-online.de 